\title{
Sobre a mudez, o silêncio e a arte (de ser psiquiatra)
}

\author{
On muteness, silence and the art (of being a psychiatrist)
}

\section{Paulo Oscar Teitelbaum}

Psiquiatra, psicanalista. Editor,Rev Psiquiatr RS.

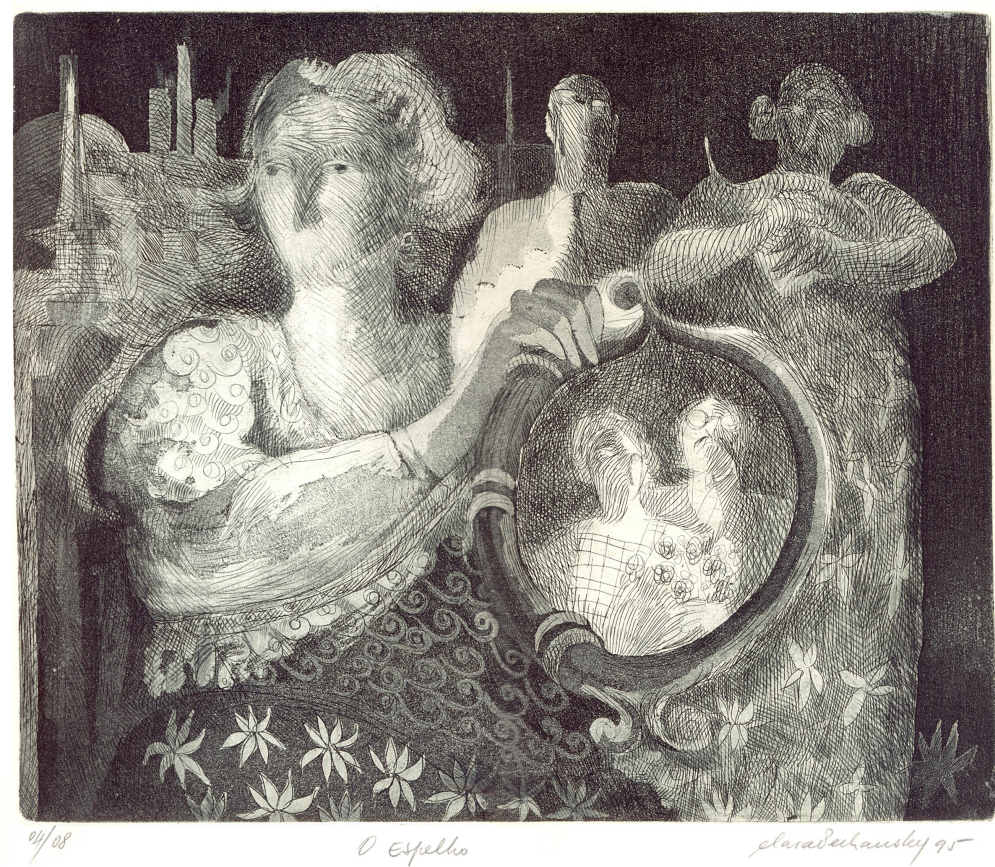

Clara Pechansky, "O espelho", gravura em metal, aguaforte e aguatinta, 24 x $30 \mathrm{~cm}, 1995$, edição de 8 exemplares.

"As figuras obrigam à interrogação, ao questionamento. E o detalhe ubíquo e inquietador: a boca obliterada, dissipada como que por encanto. É então uma dupla mudez: o silêncio desta arte, feita em silêncio; e a mudez imposta por Clara Pechansky às suas figuras."*

A escolha da capa deste número da Revista de Psiquiatria do Rio Grande do Sul representou um desafio especial. Este é o primeiro número de uma nova gestão, o que, por si só, é naturalmente um desafio. Mas mais do que isso, este é também um número que encerra um ciclo da nossa Revista e dá início a um novo, em um patamar mais sintonizado com os tempos atuais da

\footnotetext{
* Moacyr Scliar, disponível em http://www.pechansky.com.br/ gravura1.html, acesso em 12/07/2008.
}

realidade editorial de publicações científicas. Trata-se, portanto, de um momento de reflexão, interrogações e questionamentos.

Este é o contexto no qual surge a idéia de buscar a figura que ilustra nossa capa na obra forte e esteticamente impactante da reconhecida artista plástica gaúcha Clara Pechansky.

A gravura $O$ Espelho, de 1995, traz a marca do trabalho de Clara: as figuras sem boca, que transmitem tão intensamente a força inquietante do silêncio, descrita de forma precisa e igualmente forte pelas palavras de Scliar, ao falar sobre a obra da artista.

As figuras mudas (ou emudecidas) que habitam nossos pacientes e que são incapazes de se expressar de outra forma que não pela via do sintoma, são aquelas com as 
quais nós, psiquiatras de todas as orientações teóricas, procuramos nos comunicar no dia-a-dia de nosso trabalho.

Encontrar essas figuras mudas, compreender seus anseios e seus impedimentos para, quando bem-sucedidos nessa empreitada, tentar dar-lhes voz para que se expressem de forma integrada e produtiva para nosso paciente - isso é o que fazemos quando interpretamos seu mundo interno ou quando prescrevemos uma medicação.

E, para podermos bem realizar tal tarefa, é fundamental que tenhamos a capacidade de trabalhar em silêncio ou, parafraseando Scliar sobre Clara, que saibamos utilizar o "silêncio desta (nossa) arte". Nossos silêncios se contrapõem à mudez. $\mathrm{O}$ silêncio atento que busca conhecer; o silêncio inquieto que se identifica com o sofrimento do outro e sofre também; o silêncio reflexivo que, ao reconhecer e conter o sofrimento, aceitando o ainda não-conhecido, luta pela busca de um sentido; o silêncio integrador da compreensão, que gera em nossa mente uma interpretação ou uma decisão clínica.
Assim, à mudez das figuras internas do paciente deve corresponder a capacidade de silenciar do psiquiatra. Silenciar para ouvir; silenciar para sentir; silenciar para pensar; silenciar para, então, poder falar.

Penso que, deste encontro entre os nossos "silêncios", tal como os descrevi, e as figuras emudecidas do mundo interno de nosso paciente, poderão emergir novas "vozes" que, ao encontrarem expressão para além do sintoma, enriquecerão seu funcionamento psíquico, disponibilizando capacidades e potencialidades antes emudecidas.

Para concluir essas breves reflexões, vale lembrar que $O$ Espelho, de Clara, também nos inspira a pensar sobre a função de uma revista científica como instrumento de comunicação, que dá "voz" ao trabalho silencioso dos autores, permitindo assim a propagação de conhecimentos que reverterão em benefícios para nossos pacientes, objetivo final de nossa prática médica. 